organizational, educational, professional and other nature. An integral part of these efforts should be the provision of scientific support.

Key words: operational prevention, robberies, minors, operational units, the National Police.

УДК 343.542 (477)

$$
\begin{array}{r}
\text { Юхно О.О. } \\
\text { доктор юридичних наук, професор, завідувач кафедри } \\
\text { кримінального процесу та організації досудового слідства } \\
\text { Харківського національнгго університету внутрішніх справ } \\
\text { (м. Харків, Україна) }
\end{array}
$$

\title{
ПРОБЛЕМНІ ПИТАННЯ ПРОВЕДЕННЯ ОГЛЯДУ МІСЦЯ ПОДІЇ ТА ПЕРШОЧЕРГОВИХ ТАКТИЧНИХ ДІЙ СЛІДЧОГО ПРИ РОЗКРИТТІ Й РОЗСЛІДУВАННІ ЗГВАЛТУВАНЬ
}

У статті з огляду на зміни до чинного КПК України та Кримінального кодексу України, сучасних досягнень криміналістичної тактики та можливостей судової медицини, біології, генетики й різних галузей науки досліджено проблемні питання огляду місця події та першочергових слідчих ( розшукових) дій при отриманні заяв про вчинене згвалтування та способів вирішення проблемних питань у цьому напрямі, зокрема в теорії криміналістики, кримінального процесу та правозастосовній діяльності.

Ключові слова: згвалтування, огляд місця події, першопочаткові слідчі дії, чоловік, жінка, потерпілий, статева свобода особи, досудове розслідування, слідча ситуація, виявлення слідів, фіксація слідів злочину, предмети злочину.

Постановка проблеми. Як встановлено в процесі дослідження, в Україні продовжуються певні зміни в економічному й суспільному житті, поступовому дотриманні гендерної політики, удосконаленні моральних і більш демократичних підходів у взаєминах між чоловіком і жінкою. Демократизація нашої країни, бажання ввійти повноправним членом у міжнародне й зокрема Свропейське співтовариство, суттєво впливає й на розвиток та вдосконалення статевого виховання й стан протидії статевим злочинам. Попри те, що на телебаченні й у друкованих виданнях заборонена трансляція та продаж порнографічної, еротичної та подібної до них літератури,фільмів і програм, суттєвий вплив на молодь здійснюється через мережу Інтернет, у якій є можливість більш вільно знайти будь-яку інформацію з демонстрацією про відкриті сексуальні стосунки між людьми. Усе більше й більше міжнародна спільнота впливає на непротидію в країні заходам, що дозволяють пропаганду та встановлення одностатевих стосунків, здійснення легалізації проституції тощо. Останніми роками в нашому суспільстві більш терпимим з боку батьків стало ставлення до запровадження в побуті цивільних шлюбів серед молодих людей. Водночас серед підлітків у довузівських навчальних закладах все більше розповсюджуються факти насилля над однолітками. Установлюється більше фактів насилля в сім'ях, зокрема й сексуального характеру. Попри більш

(C) Юхно О. О., 2019 
демократичні вільні моральні й статеві відносини між людьми на сьогодні, кількість злочинів проти статевої свободи суттєво не зменшується, у середньому останніми роками по державі складає понад 900 злочинів. Зміни до Кримінального кодексу України (розділ IV Особливої частини із законодавчими змінами від 06 грудня 2017 року і 14 березня 2018 року) у дослідженому напрямі неоднозначно сприйнято в суспільстві, серед науковців і практичних працівників правоохоронних органів і суду. Усі факти статевих злочинів набувають громадського й суспільного резонансу, розповсюджуються засобами масової інформації, на що гостро реагують громадські та інші організації, вимагаючи від правоохоронних органів, зокрема органів досудового розслідування, професіональних дій уже на початку з' явлення інформації про вчинення злочинів проти статевої свободи та про хід їх дальшого розслідування. Указане спонукає до проведення наукових досліджень 3 проблемних питань та пошуків способів удосконалення досудового розслідування за фактами згвалтувань, а також напрацювання відповідних методик.

Аналіз останніх досліджень і публікацій. Аналіз останніх публікацій і досліджень 3 криміналістики та кримінального процесу 3 питань досудового розслідування згвалтувань, попри їх латентність, свідчить про їх деяке скорочення останніми роками. Зазначимо, що вони мають суттєвий громадський резонанс і свої особливості, а в науці продовжують бути дискусіними за окремими напрямами. Указані питання досліджували такі вчені, як: Ю. П. Аленін, Л. І. Аркуша, В. П. Бахін, Р. С. Бєлкін, В. Д. Берназ, В. В. Бірюков, О. М. Васильєв, І. О. Возгрін, А. Ф. Волобуєв, О. О. Дудоров, В. А. Журавель, А. В. Іщенко, Н. С. Карпов, О. Н. Колесниченко, Н.І. Клименко, В. О. Коновалова, М. В. Корнієнко, В. С. Кузьмічов, О. М. Кустов, В. В. Лисенко, В. К. Лисиченко, I. М. Лузгін, В. Г. Лукашевич, Г. А. Матусовський, С. С. Овчинський, Ю. Ю. Орлов, М. А. Погорецький, В. Д. Пчолкін, О. Р. Ратінов, О. С. Саінчин, М. В. Салтевський, С. В. Слінько, О. П. Снігерьов, В. М. Стратонов, В. В. Тіщенко, С. С. Чернявський, В. Ю. Шепітько, Б. В. Щур, М. П. Яблоков та інші. Серед робіт цієї спрямованості виокремемо дослідження $С$. Д. Лукьянчикова (у співавторстві) «Огляд місця події при розслідуванні окремих видів злочинів» (2005 р.), А.П.Шеремета «Злочини проти статевої свободи» (2008р.), О. О. Юхна «Запобігання, розкриття і розслідування органами внутрішніх справ вбивств та згвалтувань» (2009 р.), В. В. Шендрика, С. О. Сафронова, I. О. Крепакова, С. В. Жиліна «Боротьба 3 порнографією (2010 р.), I. О. Бандурки «Злочини проти моральності у сфері статевих стосунків» (2012 р.), В. О. Малярової «Розслідування злочинів проти моральності у сфері статевих стосунків : теорія та практика» (2013 р.), О. О. Дудорова «Злочини проти статевої свободи та статевої недоторканості особи (основні положення кримінально-правової характеристики» (2018р.) та інших учених. Згадані та інші дослідники здебільшого вивчали питання кримінальної відповідальності, кримінологічні аспекти та питання протидії згвалтуванням.

Зауважимо,що до чинного КПК України, прийнятого в 2012 році, на сьогодні внесено приблизно 575 змін і доповнень. Крім цього, унесено 
концептуальні зміни щодо кваліфікації та відповідальності за статеві злочини й до чинного закону про кримінальну відповідальність, що спричинило розширену дискусію та різновекторні погляди як серед вчених, так і серед практиків. Зазначене спонукає до переосмислення таких змін, проведення дальших досліджень, зокрема в криміналістиці та кримінальному процесі для вирішення наявних законодавчих і прикладних проблем з порушених питань.

Формування цілей. 3 огляду на нагальну потребу запровадження змін до чинного КПК України використання новітніх телекомунікаційних та інших технологій, досягнень криміналістичної тактики й можливостей судової медицини, біології, генетики, нових методик розслідування окремих видів злочинів, зокрема згвалтувань, нагальні прогалини національного законодавства, серед іншого й КПК України, виникають питання і висуваються завдання щодо вдосконалення теоретичних досліджень i проблемних питань правозастосовної діяльності, методики досудового розслідування згвалтувань.

Виклад основного матеріалу. У 2007 році було внесено зміни до кримінального процесуального законодавства України, згідно 3 якими злочини проти статевої свободи передано в підслідність із органів прокуратури до органів внутрішніх справ, а на сьогодні - до поліції. Слідчі органи поліції напрацювали певний досвід, хоча було б передчасно твердити, що вказана проблема вичерпала себе. Зокрема, про актуальність розслідування згвалтувань, їх латентність та наявні проблемні питання свідчать наведені нижче статистичні дані. У 2001 р. їх було вчинено - 1051, у 2002 p. - 1043, y 2003 p. - 1048, y 2004 p. - 964, y 2005 p. - 924, y 2006 p. - 993, y 2007 p. - 878, у 2008 р. - 880, у 2009 р. - 870, а за останні десять років у середньому їх учинено щорічно - від 880 до 945 злочинів. Висока латентність таких видів злочинів характеризується тим, що з певних причин (моральних, не бажання розповсюдження інформації про згвалтування та сором'язвливості, ухилення певної кількості винних осіб від кримінальної відповідальності під виглядом одруження тощо) потерпілі за фактами згвалтування не завжди звертаються із заявами до правоохоронних органів. Окрім указаного, останніми роками громадськість усе більше отримує інформації про супутні згвалтуванню злочини, зокрема розбещення та згвалтування неповнолітніх, що вчиняють педофіли. Методика розкриття й розслідування згвалтувань і таких видів злочинів також $є$ ще недосконалою, проте такі факти викликають значний суспільний резонанс, через що батьки неповнолітніх вимушені самостійно проводити громадське розкриття таких правопорушень та самосуд над ними, що вимагає окремого дослідження.

Анкетування засуджених за згвалтування $(11,1 \%)$, проведене А. Н. Ігнатовим, засвідчує, що причинами і спонуканням до вчинення таких злочинів у 34\% проанкетованих засуджених осіб були: демонстрація у фільмах і на телебаченні насильства й жорстокості, а також порнографії у засобах масової інформації та розповсюдження під час продажу відповідних видань. Крім цього, 63,3\% проанкетованих засуджених осіб виділили також іншу причину - безкарність у таких фактах [1, с. 556; 640]. Підтримуючи таке 
твердження, уважаємо за доцільне зазначити, що суттєвими при цьомує факти безкарності у зв'язку з примиренням між потерпілими і винними особами, що є відомим громадянам різного віку, які проживають поряд 3 такою категорією осіб, що знижує превентивний позитивний вплив на певну частину населення. До того ж, за визначенням А. П. Шеремета, фізична форма насильства під час згвалтування $є$ найбільш розповсюдженою,складаючи майже 69\% у середньому по Україні [2, с. 30], що, на нашу думку, свідчить про значну суспільну небезпеку таких видів злочинів.

Дослідження практики проведення досудового розслідування згвалтувань свідчить про те, що саме на першому етапітрапляється найбільша кількість недоліків і помилок, зокрема тактичних. Основні з них допускаютьна етапі проведення огляду місця події та першопочаткових діях при розкритті та розслідуванні такої категорії злочинів. Серед іншого, науково-технічний прогрес надає можливість використовувати під час розслідування та розкриття новітні досягнення науки, зокрема телекомунікаційні здобутки та використання мережі Інтернет, а також можливості судової медицини, біології, генетики, загальної медицини тощо. Суттєвий вплив на криміногенний стан у державі справляє вчинення злочинів, скоєних на території проведення операції Об'єднаних сил в частині Луганської та Донецької областей. Указане спонукає до дослідження сучасного стану розслідування згвалтуваньз використанням останніх досягненьнауки, а також попереднього багаторічного позитивного досвіду тарозвитку криміналістичної тактики, кримінального процесу, судової медицини та інших галузей науки. Зокрема, одним із суттєвих досягнень науки на сьогодні $є$ можливість проведення експертизи ДНК-молекулярногенетичного ідентифікаційного аналізу біологічних слідів людини, що проводиться для ідентифікації осіб, у цьому разі за слідами потерпілої і підозрюваного.

При розслідуванні цієї категорії злочинів огляд місця події є основним, а в окремих випадках - єдиним джерелом здобуття речових доказів. Саме від своєчасності та чіткості організації огляду місця події залежить успішне розкриття й розслідування кримінальних проваджень. За визначенням В. Ю. Шепітька виявлення слідів і встановлення причинних зв'язків між ними дають змогу побудувати картину події, вірогідні або дійсні моделі злочину, розкрити механізм його вчинення. Дослідження цих слідів або речових доказів має вказати на особу злочинця, особу потерпілого та обставини події, виявити інші негативні обставини й сліди приховування злочину [3, с. 238].

Згідно 3 класичною формулою до першочергових дій під час розслідування згвалтування (ст. 152 КК України), за визначенням С. Д. Лукьянчикова, належать пошук і затримання злочинця, а також огляд місця події, що може проводитися до реєстрації в СРДР заяви потерпілих за такою категорією. У цьому разі доцільно використовувати допомогу потерпілої, яка найбільш достовірно може визначити особу, яка вчинила 
злочинні дії. Огляд місця події проводять також здебільшого за участю потерпілої після іï попереднього опитування чи допиту, приділяючи особливу увагу виявленню й опису в протоколі місця згвалтування, його розташування. Якщо, скажімо, воно вчинено на певній місцевості, то треба зорієнтувати вказане місце відносно дороги, найближчих житлових будинків та інших орієнтирів чи координат. Під час огляду місця події з'ясовують обстановку на момент учинення злочину (яке освітлення, чи пролягає поблизу вулиця або дорога, як близько розташовані будинки, куди виходять їх вікна, чи мешкають у сусідніх кімнатах люди тощо). На нашу думку, у разі невстановлення місця знаходження потерпілої після вчинення згвалтування або потерпілих, які перебувають у тяжкому фізичному стані, або в разі коли їх убито, а також наявності певних показань свідків про отриману щодо цього інформацію та про орієнтовну територію їх знаходження доцільно було б для скорочення часу на пошуки використати сучасний літальний повітряний апарат «дрон». При огляді місця події важливо оцінити, чи збігається обстановка на місці події з отриманими раніше показаннями або поясненнями заявниці (заявника); виявити сліди, які є характерними для згвалтування, або відшукання і виявлення речей, що належать як злочинцеві, так і потерпілій (нижня білизна, елементи одягу, мобільні телефони, сумка, гудзик, окуляри, авторучка, носова хустинка, недопалок та інші особисті речі й документи). Основне завдання слідчого - виявити ознаки злочину для дальшої ідентифікації злочинця; установити, чи є сліди боротьби; перевірити, чи відповідають обстановці місця події свідчення потерпілої. Слідчий має прагнути знайти, оглянути та вилучити взуття або одяг злочинця та інші речові докази. Необхідно завжди пам'ятати про спільне передавання слідів, яке є, коли два об'єкти або особи (потерпіла і винна особа) вступають у контакт одне з одним. Злочинці, учиняючи згвалтування, заподіяння тілесних ушкоджень, залишають докази (сліди біологічного походження).Пошук слідів біологічного походження має деякі особливості, пов'язані зі специфічними властивостями таких об'єктів, як кров, сперма, слина, частини тканин, волосся.

У процесі огляду, за визначенням В. О. Малярової, потрібно звернути увагу на можливість утворення на одязі, взутті та тілі гвалтівника, скажімо, нашарувань грунтових забруднень і рослинних частинок і взяти їх проби для експертних досліджень. Пошук мікрочастинок треба починати з огляду місця події та виявленому при цьому одягу (важливо дотримуватися застережних заходів, які унеможливлюють їх втрату, а також привнесення учасниками огляду сторонніх мікрочастинок або слідів). Для цього потрібно підготувати необхідні технічні засоби: лупи, ліхтар, скальпель, пінцет, паперові пакети, технічні засоби, що виявляють необхідні біологічні та інші сліди. Ми підтримуємо твердження, що проводити пошук рекомендовано тільки при якісному освітленні, а в разі здійснення такої дії у вечірній чи нічний час, доцільно проводити ще й додатковий огляд місця події у денний час [4, с. 150-153]. Предмети доцільно розглядати як у прямому, так і у світлі, що косо падає, уникаючи їх різкого струшування. Предмет, який оглядають, кладуть на аркуш цупкого паперу. Після закінчення огляду потрібно ретельно 
вивчити аркуш, на якому лежав предмет, оскільки там можуть виявитися мікрочастинки, які випадково впали, або впали під час огляду предмета, чи 3' явилися під час учинення злочину. На ділянці місцевості встановлюють місце 3 витоптаною землею, зім'ятою травою, поламаними кущами, волокнами одягу, а в приміщенні - розбитий посуд та віконне скло, плями крові, сперми та слини. Особливу увагу на місці події треба звернути на виявлення різних мікрочасток, які могли потрапити на одяг або тіло гвалтівника (глина, пісок, частки рослин та їх зерна, солома, сіно, волосся тощо).

Після реєстрації в ЄРДР до тимчасового доступу та вилучення предметів i документів вдаються переважно на початковій стадії розслідування перед оглядом одягу потерпілої та підозрюваного, якщо це не було зроблено під час огляду місця події. Цей захід забезпечення кримінального провадження та слідча дія мають провадитися в усіх випадках розгляду заяви чи повідомлення за фактом згвалтування, оскільки на одязі потерпілої та підозрюваного майже завжди залишаються сліди насильства (сліди тілесного пошкодження тіла, наявність волосяного покрову, плям крові, сперми тощо), які надалі використовують для проведення відповідних експертиз згідно з новелами до КПК України після погодження відповідного клопотання з прокурором до слідчого судді, а їхні заключення використовуються як докази. Для цього ж вилучають одяг, який був на потерпілій і підозрюваному під час події. Зауважимо, що окремо доцільно здійснювати огляд одягу, постільної і нижньої білизни тощо, які проводяться на місці огляду місця події для виявлення та фіксації можливих слідів. До того ж вологі предмети одягу треба просушити (тільки не на сонці чи біля відкритого вогню). Для їх дослідження застосовують науковотехнічні засоби (лупу, ультрафіолетовий освітлювач, наприклад УФО-4А тощо). За потреби для огляду запрошують спеціалістів (судово-медичного експерта, експерта-криміналіста чи інспектора-криміналіста (нова посада у районних відділах Національної поліції України)). Потрібно ретельно оглянути одяг із зовнішнього та внутрішнього боку: кишені, манжети, застібки, шви. Навіть якщо під час огляду не виявлено нічого зорово і суттєво наявного, але є підстави передбачати, що на одязі є якісь сліди, попередньо упакувавши (для цього його розкладають на папері й, перекладаючи ним, згортають у рулон). Мікрочастинки вилучають окремо, якщо є побоювання, що під час транспортування тощо вони можуть бути загублені чи пошкоджені. Упакування забезпечує ізоляцію предметів від зовнішнього впливу. У нього вкладають (наклеюють зверху) бирку з поясненнями (де, коли й ким проведена виїмка). Упакований одяг чи інше опечатують, проставляючи на бирці підписи слідчого і понятих. На місці вчинення згвалтування часто виявляють сліди та інші речові докази в справі: предмети туалету як потерпілої, так і злочинця; сліди опору з боку потерпілої, які дають змогу з'ясувати: чи був статевий акт здійснений усупереч волі потерпілої (підтвердження того, чи застосовував злочинець фізичне або психічне насильство) або чи був використаний ії безпомічний стан та чи виражався він можливо у фізичній чи психічній безпорадності потерпілої. Також важливе значення має вивчення й огляд обстановки згвалтування. 
Підлягають з'ясуванню всі деталі розвитку злочину: чи був гвалтівник знайомий потерпілій; установлення місця зустрічі; шлях і спосіб руху до місця події; зміст розмов як до події, під час ¥ї, так і після неї; конкретні дії злочинця тощо [5, с. 69-70].

Зазначимо, що ці об'єкти мають вивчатися за двома напрямами. У першому - вивчається форма слідів біологічного походження, що дає змогу змоделювати механізм злочину. Таке дослідження має проводитися на місці їх знаходження, оскільки в процесі вилучення крові зазвичай порушується їх форма й топографія. Ця інформація надає можливість встановити місце розташування та стан потерпілої і злочинця в момент згвалтування та спричинення тілесних ушкоджень, а також траєкторію пересування потерпілої після згвалтування, особливі прикмети злочинця, знаряддя злочину тощо. За слідами падіння крапель крові можна встановити висоту розміщення рани, а в деяких випадках - і зріст людини, темп тї пересування. За формою плям крові визначають напрям завданих ударів, а потьоки крові дають змогу висунути версії про розташування предметів, тіла, послідовність спричинення ушкоджень. При вивченні плям крові можуть бути виявлені сліди папілярного візерунка рук, босих ніг, слідів взуття, одягу у вигляді їх відбитків і знарядь учинення злочину. Велике значення для виявлення доказів згвалтування мають одержані при дослідженні слідів крові дані про наявність ушкоджень на тілі злочинця, їх види та локалізацію.

$\mathrm{У}$ другому випадку вивчається природа виявлених слідів, установлюється їх наявність, видова, групова і статева належність. Дослідження експертиз ДНК проводять у лабораторіях ДНДЕКЦ МВС України м. Київ і НДЕКЦ МВС України Харківської, Київської, Вінницької, Львівської, Миколаӥвської, Запорізької областей. Крім цього, такі ж експертизи проводять в бюро судово-медичних експертиз Київської, Одеської та Дніпропетровської областей. До того ж такі експертизи ДНК проводять за різновидами : 1) ДНК ядрова - у разі вилучення повноцінного ядра клітин та 2) мітохондріальна ДНК - у разі вилучення пошкоджених клітин (наприклад, волосини без цибулини тощо). Перед проведенням таких експертиз доцільна консультація з відповідними фахівцями, а ще краще доцільна їхня присутність і участь під час огляду місця події. Аналіз кримінальних проваджень свідчить, що здебільшого заподіяння тілесних ушкоджень, згвалтувань здійснюеться активним фізичним контактом злочинця та потерпілої особи, унаслідок чого на їхньому тілі та одязі залишаються сліди біологічного та іншого походження сторони, яка здійснює опір. Пошук слідів злочинця в приміщеннях проводиться 3 урахуванням найбільш вірогідних їх носіїв. Вони можуть бути вилучені зі знарядь учинення злочину, посуду, недопалків, із предметів, що належать потерпілій особі, але знайдених у нетипових для них місцях, а також загублених злочинцем під час супротиву потерпілої, або під нігтями винного. Зауважимо, що злочинець міг залишити сліди крові, волосся та інші об'єкти на різних речах не тільки під час боротьби з потерпілою, але й у момент подолання перешкод через злом чи пошкодження. Тому при огляді місця події треба вести пошук таких слідів у місцях можливого проникнення в приміщення та виходу з нього. Зокрема, при самопораненні кров злочинця 
може знаходитися на пошкодженому склі й віконних рамах, балконних гратах, пристроях запирання і дверях, на підлозі, шпалерах поблизу вікон і дверних отворів, вимикачах тощо. Треба пам'ятати про можливість поранення рук злочинця при застосуванні ним як знаряддя злочину ножа без обмежувача, бритви, кастета, що не відповідає за розміром пальцям злочинця або має завусини. 3 огляду на це пошук слідів біологічного походження треба вести не тільки на знаряддях злочину, а й на інших предметах, яких злочинець міг торкатись. Перевіряючи версії про поранення злочинця при огляді місця події, треба ретельно проводити пошук слідів крові на предметах, якими він міг скористатися для видалення крові 3 рук на завісах, рушниках, ганчірках, краях килимів, нижній частині меблів, їх оббивки тощо. 3 урахуванням конкретних обставин справи потрібно здійснювати також і пошук крові чи інших виділень потерпілої особи. Не треба нехтувати для цього й оглядом брудної білизни, ящиків для сміття тощо. Під час старанного маскування злочинів, злочинець намагається знищити сліди крові потерпілої особи, змиваючи їх водою. У такому разі бажано залучати спеціаліста-біолога до участі в огляді місця події. За його допомогою можна знайти сліди розчиненої крові чи інших виділень у ванні або раковині, на фільтрах водостоку. Такі сліди можуть зберігатися протягом тривалого часу. Усе зазначене не обмежується методичними рекомендаціями та алгоритмом дій для слідчого.

Висновки. Одним із головних аспектів і проблемних питань досудового розслідування та розкриття згвалтувань $є$ належне здійснення огляду місця події, під час якого у правозастосовній діяльності можливе допущення окремих недоліків і помилок. Слідчі мають правильно використовувати відповідну методику й тактику, зокрема з огляду місця події в такій категорії злочинів. На нашу думку, з психологічного й тактичного погляду таку категорію кримінальних проваджень мають розслідувати особи жіночої статі, якщо потерпілою є жінка чи неповнолітня дівчина. Досягнення між ними психологічного контакту дасть можливість із самого початку більш ефективно проводити досудове розслідування в такій категорії злочинів. Специфіка вчинення згвалтувань вимагає залучення до огляду місця події відповідних фахівців, зокрема з виявлення біологічних слідів і слідів ДНК як потерпілої особи, так і підозрюваної для дальшої ідентифікації таких слідів. У процесі реформування органів Національної поліції України для надання методичної та практичної допомоги слідчому при виявленні й фіксації слідів на місці огляду події при районних відділах поліції введено нову посаду інспектор-криміналіст, який підпорядковується відповідним відділам слідчих управлінь ГУНП областей. Для здійснення пошуку як потерпілих, так і підозрюваних на значній території та економії часу на їхні пошуки доцільно використовувати такий літальний повітряний апарат, як «дрон». Останніми роками в Україні розширюється мережа державних закладів із проведення експертиз ДНК, що дасть змогу більш ефективно розкривати та розслідувати згвалтування та вбивства. Зазначимо, що попри вдосконалення нових криміналістичних методик із розслідування згвалтувань доцільно використовувати й напрацювання та досвід попередніх років, а також 
упроваджувати можливості додаткових знань з інших галузей науки. Утім, порушені питання не є вичерпними й підлягають окремому дослідженню чи науковому вивченню.

\section{Використані джерела:}

1. Ігнатов О. М. Протидія загальнокримінальній насильницькій злочинності в Україні : монографія. Харків : Диса Плюс. 2013. 650 с.

2. Шеремет А. П. Злочини проти статевої свободи : монографія. Чернівці : ТОВ «Видавництво «Наші книги». 2007. 216 с.

3. Криминалистика. Криминалистическая тактика и методика расследования преступлений : учебник для студ. юрид. вузов и факультетов. Харьков : Одиссей. 2001. С. 238.

4. Огляд місця події при розслідуванні окремих видів злочинів: наук.практ.посібник / за ред. Н. І. Клименко, П. В. Коляди. Київ : Юрінком. Інтер. 2005. C. $69-70$.

5. Малярова В.О. Розслідування злочинів проти моральності у сфері статевих стосунків: теорія та практика : монографія / за ред. Д-ра юрид. наук, чл.кор. НАПрН України С. М. Гусарова. Харків : Диса плюс. 2013. 422 с.

Стаття надійшла до редколегї 24.01.2019

Юхно А. А. , доктор юридических наук, профессор, заведующий кафедрой уголовного процесса и организации досудебного следствия Харьковского национального университета внутренних дел (г. Харьков, Украина)

Проблемные вопросы проведения осмотра места происшествия и первоначальных тактических действий следователя при раскрытии и расследовании изнасилований

В статье с учетом изменений в действующем УПК Украины и Уголовном кодексе Украины, новейших достижений криминалистической тактики и возможностей судебной медицины, биологии, генетики и других областей науки исследованы проблемные вопросы осмотра места происшествия и первоначальных следственных (розыскных) действий при получении заявлений об изнасиловании и путей решения проблемных вопросов в этом направлении, в частности в теории криминалистики, уголовного процесса и правоприменительной деятельности.

Ключевые слова: изнасилование, осмотр места происшествия, первоначальные следственные действия, мужчина, женщина, потерпевший, половая свобода, досудебное расследование, следственная ситуация, выявление следов, фиксация следов преступления, предметы преступления.

Yukhno O. Some Problematic Issues of the Methodology of Conducting Inspection of the Scene and the Investigator's First-Priority Tactical Actions in the Disclosure and Investigation of Rapes

The author of the article, due to changes in the current Criminal Procedure Code of Ukraine and the Criminal Code of Ukraine, the modern achievements of biology, genetics and various branches of science, studied the problem issues of the method of inspection of the scene and the primary investigative actions that are conducted after applications for rape. Also the author of the article reveiwed the ways of solving problems in this direction, in particular in the theory and practice of forensic science, criminal procedure and law enforcement activities. The author of the article, according 
to the previously conducted scientific researches of various scholars and personal experience, enlighten the most characteristic and necessary issues, tactical actions of the investigator, which it is expedient to consider and carry out in responding to the statements of victims of rape and taking into account during the inspection of the scene of crime. With a view to disclosing a full, prompt and impartial investigation of such a category of proceedings, attention was drawn to the involvement of relevant specialists, experts, specialists in various fields of knowledge, as well as new specialists in the district departments of the National Police of Ukraine - criminological inspectors. The indicated specialists will assist the investigator in identifying, fixing, verifying and evaluating evidence in the event of an overview of the location of the event, in order to develop relevant versions in detecting such crimes, implementing the most effective proof process and preventing errors in such categories of criminal proceedings. Provides concrete recommendations on the preliminary interview of the injured before the inspection of the scene and cooperating with it during this. The author studied the method of inspection the scene in the part of the search on the site of the event and anchoring to a specific territory or place of crime, as well as finding objects, documents, clothing items, personal belongings, or fragments of both the victim and the guilty person. It is emphasized on the strict observance of the method of detection, removal and preservation of biological and other traces that have a short shelf life with the use of modern technical and forensic means. The results of the study in the article draw specific conclusions that are recommended for use in scientific research and law enforcement activities in this direction.

Key words: rape, inspection of the scene, initial investigation actions, husband, woman, victim, sexual freedom of the person, pre-trial investigation, investigation situation, detection of traces, fixation of traces of crime, objects of crime. 